FELIPE ESMANHOTO MATEO

\title{
O PRINCÍPIO DA BOA-FÉ OBJETIVA, COMO FUNDAMENTO DA RESPONSABILIDADE CIVIL PÓS-CONTRATUAL NO ORDENAMENTO JURÍDICO BRASILEIRO: Pressupostos, natureza jurídica e efeitos
}

Dissertação de mestrado

Orientador: Professor Titular Dr. Fernando Campos Scaff

UNIVERSIDADE DE SÃO PAULO

FACULDADE DE DIREITO

São Paulo-SP

2020 


\title{
O PRINCÍPIO DA BOA-FÉ OBJETIVA, COMO FUNDAMENTO DA RESPONSABILIDADE CIVIL PÓS-CONTRATUAL NO ORDENAMENTO JURÍDICO BRASILEIRO: Pressupostos, natureza jurídica e efeitos
}

\begin{abstract}
Dissertação apresentada a Banca Examinadora do Programa de Pós-Graduação em Direito, da Faculdade de Direito da Universidade de São Paulo, como exigência parcial para obtenção do título de Mestre em Direito, na área de concentração Direito Civil, sob a orientação do Professor Titular Dr. Fernando Campos Scaff.
\end{abstract}

UNIVERSIDADE DE SÃO PAULO

FACULDADE DE DIREITO

São Paulo-SP

2020 
Mateo, Felipe Esmanhoto

o princípio da boa-fé objetiva, como fundamento da responsabilidade civil pós-contratual no ordenamento jurídico brasileiro: pressupostos, natureza jurídica e efeitos; Felipe Esmanhoto Mateo; orientador Fernando Campos Scaff -- São Paulo, 2020.

$248 f$.

Dissertação (Mestrado - Programa de Pós-Graduação em Direito Civil) - Faculdade de Direito, Universidade de São Paulo, 2020

1. Contratos. 2. Boa-fé. 3. Deveres laterais. 4. Responsabilidade civil. 5. Culpa post pactum finitum. I. Scaff, Fernando Campos, orient. II. Título. 
Nome: MATEO, Felipe Esmanhoto

Título: O princípio da boa-fé objetiva, como fundamento da responsabilidade civil póscontratual no ordenamento jurídico brasileiro: pressupostos, natureza jurídica e efeitos

Dissertação apresentada a Banca Examinadora do Programa de Pós-Graduação em Direito, da Faculdade de Direito da Universidade de São Paulo, como exigência parcial para obtenção do título de Mestre em Direito, na área de concentração Direito Civil, sob a orientação do Professor Titular Dr. Fernando Campos Scaff.

Prof. Dr.

Prof. Dr.

Prof. Dr. 
À Priscilla, por tudo. 


\section{AGRADECIMENTOS}

Esta dissertação conclui mais um ciclo de minha vida acadêmica. Como nada se faz sozinho, é necessário agradecer algumas pessoas.

De proêmio, externo minha gratidão ao Prof. Dr. Fernando Campos Scaff, exemplo de seriedade, dedicação e retidão na vida acadêmica, pela orientação segura e enriquecedora. Agradeço, ainda, pela confiança em me aceitar no Mestrado, pelo incentivo externado desde nosso primeiro encontro, como também pela troca de ideias, pelos ensinamentos e diálogos constantes que foram fundamentais para este trabalho.

Ao Prof. Dr. Luiz Antonio Rizzatto Nunes, cuja trajetória de vida me inspira admiração desde os tempos de graduação, agradeço por tornar possível este sonho, ao me apresentar ao Prof. Fernando Campos Scaff.

Ao Prof. Dr. Guilherme Ferreira da Cruz, magistrado da melhor estirpe e professor apaixonado pela academia, o qual sigo como modelo de conduta para a vida, agradeço pelos constantes incentivos e conselhos profissionais e acadêmicos.

Agradeço também ao Prof. Dr. Cláudio Luiz Bueno de Godoy por me acolher, ainda no ano de 2016, como aluno especial, dando início à minha trajetória nas Arcadas.

Registro ainda minha gratidão ao Prof. Dr. Marco Fábio Morsello, pelos direcionamentos dados nos intervalos de suas aulas, como também, de forma especial, pelos apontamentos efetuados durante o período de qualificação. 
MATEO, Felipe Esmanhoto. O princípio da boa-fé objetiva, como fundamento da responsabilidade civil pós-contratual no ordenamento jurídico brasileiro: pressupostos, natureza jurídica e efeitos. 248f. Dissertação (Mestrado) - Faculdade de Direito, Universidade de São Paulo, São Paulo, 2020.

\section{RESUMO}

Este trabalho busca demonstrar como a funcionalização do princípio da boa-fé objetiva pode ser utilizada como fundamento de uma responsabilidade civil pós-contratual no sistema jurídico brasileiro. Apesar dos parcos julgados existentes sobre o tema - e relatados ao longo da dissertação - certo é que a responsabilização do agente causador do dano, em tais casos, é revestida de certo sentimento de justiça. Contudo, o sistema jurídico não pode contentarse com o mero sentimento pessoal do julgador. É necessária uma fundamentação adequada. Dentro desse esquadro, inicia-se o trabalho explorando a evolução das fontes das obrigações, contrapondo a autonomia privada aos limites impostos pelo ordenamento e às suas fontes heterônomas. Busca-se, assim, definir quais elementos atuam na construção do conteúdo contratual. Tendo forte influência sobre a conduta esperada dos contratantes, mormente pela imposição de deveres laterais, e, novamente, não podendo ser relegada a meros fatores subjetivos, parte-se para o estudo da boa-fé objetiva, analisando seus vetores materiais e suas funções correlatas. Seu espectro de incidência, contudo, não é limitado às fases de formação e execução. Dessa forma, analisa-se sua concreção desde o contato até a fase posterior ao adimplemento. Surge então a questão: se ainda existem deveres a serem observados, no que consiste a pós-eficácia? Para responder a indagação, é necessária uma digressão sobre a noção hodierna de obrigação complexa e adimplemento satisfatório. Feito isso, é possível chegar a alguns fundamentos, dentre eles a própria boa-fé, para a responsabilidade civil póscontratual. Por fim, a presente dissertação debruça-se sobre sua natureza jurídica e as possíveis pretensões do lesado. Com isso, pretende-se trazer uma fundamentação adequada, por meio da boa-fé objetiva, para a responsabilidade por culpa post pactum finitum.

Palavras-chave: Contratos, Boa-fé, Deveres laterais, Pós-eficácia, Responsabilidade civil, Culpa post pactum finitum 
MATEO, Felipe Esmanhoto. The principle of good faith as the foundation of postcontractual liability in the Brazilian legal system: assumptions, legal nature and effects. 248f. Thesis (Master) - Law School, University of São Paulo, São Paulo, 2019.

\begin{abstract}
This thesis seeks to demonstrate how the functions of the principle of good faith can be used as the foundation for post-contractual liability in the Brazilian legal system. Despite the few judgments that exist about the subject - and reported throughout the dissertation - it is certain that the liability of the author of the damage, in such cases, has a certain amount of justice. However, the legal system cannot be content with the mere personal feeling of the judge. Proper reasoning is required. Within this framework, this thesis begins by exploring the evolution of the sources of obligations, contrasting private autonomy with the limits imposed by the law and the heteronomous sources. Thus, we seek to define which elements act in the construction of contractual content. Having a strong influence on the expected conduct of contractors, especially the imposition of implied duties, and, again, cannot be relegated to mere subjective factors, we start to study the duty of good faith, analyzing its material vectors and their related functions. Its incidence spectrum, however, is not limited to the formation and performance phases. Thereby, its analyzed from the contact of the parties until the postperformance phase. Then a question arises: If there are still duties to be observed, what does post-efficacy means? To answer the question, a digression on today's notion of complex obligation and satisfactory perfomance is required. That done, it is possible to come up with some foundations, including good faith itself, for post-contractual liability. Finally, the present dissertation explore its legal nature and the possible claims of the injured party. Thereat is intended to provide adequate foundation, through the principle of good faith, for culpa post pactum finitum liability.
\end{abstract}

Keywords: Contracts, Good Faith, Implied terms, Post-effectiveness, Liability, Culpa post pactum finitum. 


\section{SUMÁRIO}

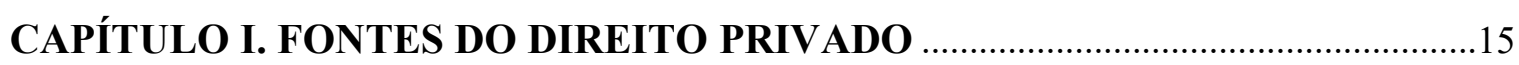

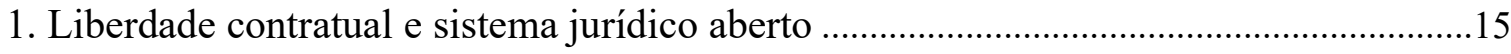

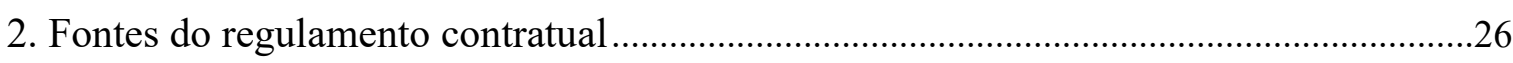

2.1. Cláusulas gerais; princípios e conceitos jurídicos indeterminados ....................................

CAPÍTULO II. O DIREITO OBRIGACIONAL E A BOA-FÉ OBJETIVA................51

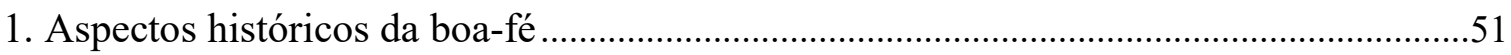

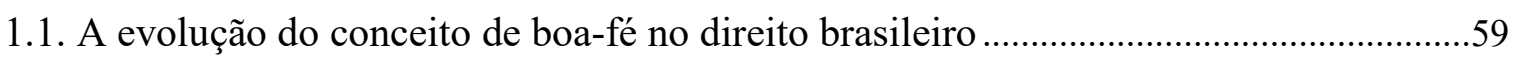

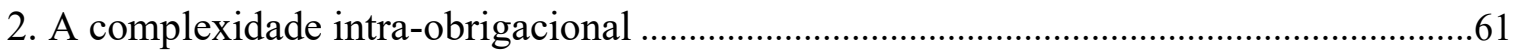

3. Violação positiva do contrato e deveres de prestação e de proteção....................................66

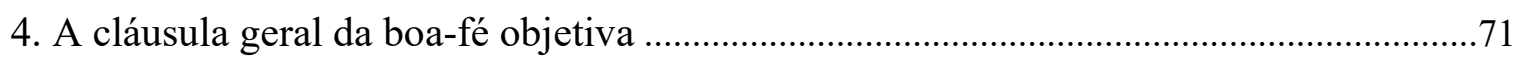

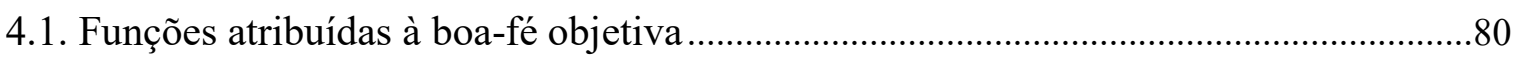

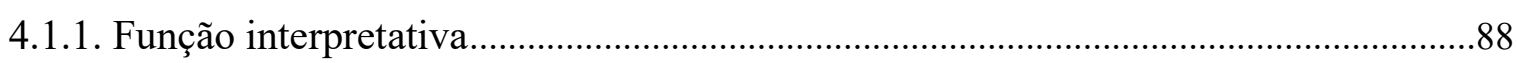

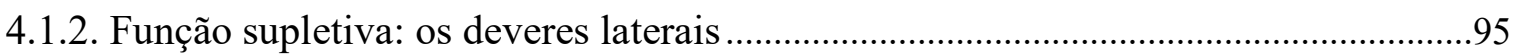

4.1.2.1. Deveres laterais em espécie e sua incidência na fase pós-contratual ......................101

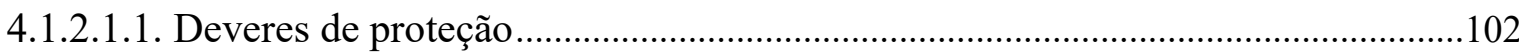

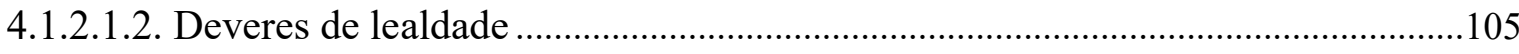

4.1.2.1.3. Deveres de esclarecimento ou informação ................................................................106

4.2. A boa-fé nas diversas espécies de relações jurídicas: Pontos de aproximação e a diferença de densidade na criação dos deveres.............................................................109

CAPÍtULO III. PÓS-EFICÁCIA DAS OBRIGAÇÕES: ASPECTOS

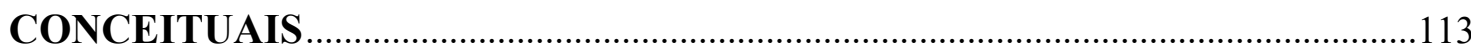

1. Identificação do período e noção de relação pós-contratual ………………………….......113

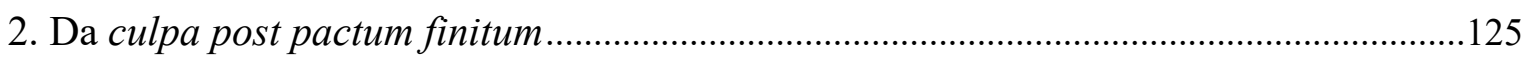

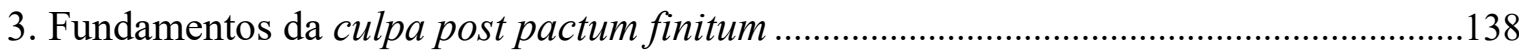

3.1. Teses negativistas e a identificação das variadas espécies de pós-eficácia latu

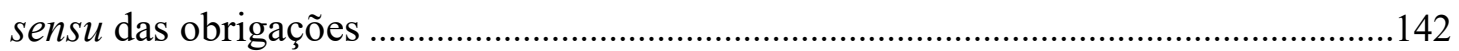

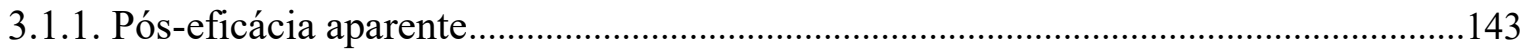

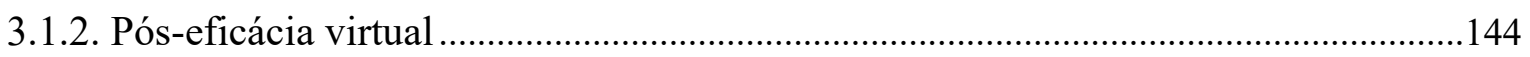

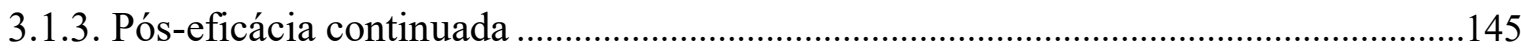

3.2. Pós-eficácia em sentido estrito: a boa-fé objetiva como fundamento da culpa post pactum finitum.

3.3. Fundamentos adicionais para a culpa post pactum finitum elencados pela doutrina 
CAPÍTULO IV. PÓS-EFICÁCIA DAS OBRIGAÇÕES E

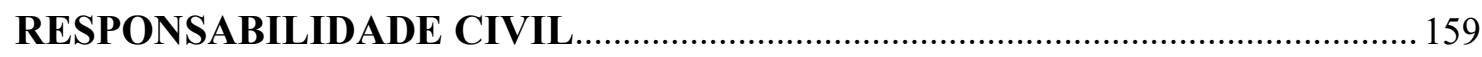

1. Responsabilidade civil extracontratual e contratual: semelhanças e diferenças .............159

2. O conceito de mora e inadimplemento no Código Civil de 2002 .................................... 173

2.1. A assimilação da doutrina da violação positiva do contrato pelo direito brasileiro ... 180

3. Natureza jurídica da responsabilidade civil pós-contratual: exposição da divergência.

3.1. A natureza contratual da responsabilidade civil pelo descumprimento de deveres

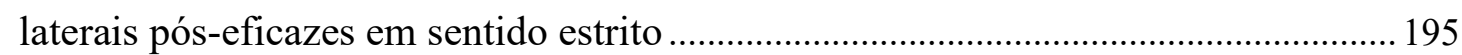

3.2. A terceira via da responsabilidade civil .................................................................... 211

4. Consequências do descumprimento de deveres pós-eficazes em sentido estrito: direito formativo extintivo, perdas e danos e pedido cominatório ....................................213

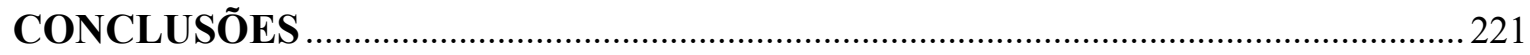

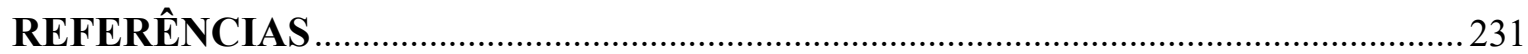

Doutrina

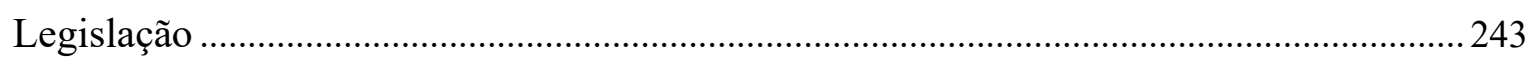

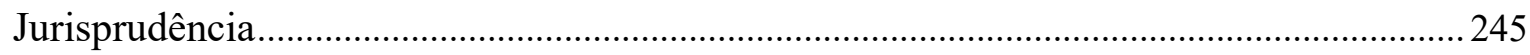




\section{INTRODUÇÃO}

A presente dissertação busca o estudo da cláusula geral da boa-fé objetiva, inserta no artigo 422 do Código Civil, como fundamento legal de uma eventual responsabilidade civil pós-contratual em nosso ordenamento jurídico.

Com a declínio do individualismo e do dogma da vontade, o conteúdo da relação contratual passou a transcender o mero texto escrito, resultando em uma aproximação do direito com a ética.

Há muito já se alude às transformações gerais do Direito das Obrigações, que passou a ser compreendida, não mais como simples relação de crédito e débito, mas como um processo dinâmico dirigido à realização de seu fim. Tomada em sentido lato, a obrigação abrange todos os direitos, inclusive os formativos, pretensões e ações, deveres, exceções e posições jurídicas, de modo que não se limita, apenas, ao cumprimento da prestação principal, mas sim a um conjunto de atividades necessárias à satisfação do interesse do credor ${ }^{1}$.

Partindo da premissa de imposição às partes de deveres não previstos expressamente no instrumento contratual, o primeiro capítulo da dissertação dedica-se ao estudo das fontes do direito privado, que, tradicionalmente, se consubstanciariam na lei e no contrato. Entretanto, atualmente, os princípios jurídicos igualmente comandam o nascimento e o desenvolvimento das obrigações.

Karl Larenz já dispunha que:

"para toda relación jurídica, cualquiera que sea su estructura, rige el principio de cumplir la prestación con fidelidad a la palabra dada o a la obligación fundamentada de cualquier modo que sea, sin defraudar la confianza de la otra parte, es decir cumplir la prestación según la buena $\mathrm{fe}(\xi 242))^{\prime 2}$

No direito brasileiro, o Código Civil de 2002 previu em seu artigo 422, o dever dos contratantes de observarem a cláusula geral da boa-fé objetiva, permitindo o reenvio do magistrado a valores até então submetidos a outras ciências, possibilitando uma aproximação

\footnotetext{
${ }^{1}$ SILVA, Clóvis do Couto e. A obrigação como processo. Reimpr. Rio de Janeiro: Editora FGV, 2006. p. 17-19. ${ }^{2}$ LARENZ, Karl. Derecho de obligaciones. Traducción de Jaime Santos Briz. Madrid: Editorial Revista de Derecho Privado, 1958. t. 1, p. 20-21.
} 
do direito com a ética, com vistas a concretização do programa obrigacional desenhado pela autonomia privada, com a imposição de deveres de conduta não previstos expressamente no instrumento contratual.

Malgrado as críticas que possam ser realizadas ao texto do artigo 422 do Código Civil - as quais constam no corpo da própria dissertação - certo é, também, que a incidência do princípio da boa-fé não é limitada à fase de conclusão e execução da avença. Como já dispõem os enunciados 25 e 170 das Jornada de Direito Civil, realizadas pelo Conselho de Justiça Federal, deve ser observado desde as tratativas preliminares, até mesmo após o término da avença.

Cumpre ressaltar, aliás, que a noção de boa-fé não é nova no ordenamento jurídico brasileiro. O próprio Código Comercial de 1850 já a previa no artigo 131, apesar deste não ter despertado a atenção que merecia, na época, da doutrina e jurisprudência.

A noção que há deveres que se protraem no tempo para além do cumprimento igualmente não é novidade na doutrina pátria. Couto e Silva já a expunha, na década de 60, ao apresentar sua tese de livre-docência:

"Outros, porém, surgem desvinculados da vontade, núcleo do negócio jurídico, por vezes ligados aos deveres principais e deles dependentes, por vezes possuindo vida autônoma. Os deveres desta última categoria, chamados independentes, podem perdurar mesmo depois de adimplida a obrigação principal ${ }^{\prime 3}$

Mas há, ainda, a necessidade de se estabelecer os contornos desses deveres ditos póseficazes, oriundos da cláusula geral da boa-fé objetiva, e de que maneira continuam exigíveis no período pós-contratual. É o que se buscará responder no capítulo II, ao relacionar o princípio da boa-fé com a tutela da confiança e à primazia das relações subjacentes.

O capítulo III, por sua vez, dedica-se ao estudo dos aspectos teóricos da pós-eficácia, que não teve a mesma atenção dedicada ao estudo da culpa in contrahendo ${ }^{4}$. Não se desconhece que vários foram os motivos que contribuíram para este quadro, dentre eles, a própria escassez de casos submetidos ao exame dos Tribunais; a noção geral de que, após o cumprimento da prestação, as partes não conservam nenhuma obrigação em relação ao contrato anterior; a ausência de linguagem claramente remissiva à culpa post pactum finitum,

\footnotetext{
${ }^{3}$ SILVA, Clóvis do Couto e. A obrigação como processo, cit., p. 38.

${ }^{4}$ MENEZES CORDEIRO, António Manuel da Rocha e. Da pós-eficácia das obrigações. In: MENEZES

CORDEIRO, António Manuel da Rocha e. Estudos de direito civil. Coimbra: Almedina, 1987. v. 1, p. 149.
} 
por parte dos poucos julgados sobre o tema ${ }^{5}$, e a falta de uma fundamentação adequada para o instituto ${ }^{6}$.

Contudo, esse quadro apenas reforça a importância do tema, impondo-se compreender a real amplitude da culpa post pactum finitum. Mas há dificuldades em seu exame. Apesar da aprovação dos enunciados acima, reconhecendo a pós-eficácia, Menezes Cordeiro elenca teorias negativistas elaboradas pela doutrina. Para estas, as manifestações ditas pós-eficazes, em verdade, nada mais seriam do que simples eficácia atual, seja porque a extinção contrato é o fato constitutivo da nova obrigação, seja porque determinado dever apenas permaneceu exigível.

Tais teoria, acabaram por desenvolver as noções de pós-eficácia virtual, aparente e continuada, que, como se demonstrará, não se confundem com a culpa post pactum finitum, ou pós-eficácia em sentido estrito. Existem, ainda, outras dificuldades a serem enfrentadas, como a própria fixação do que seria o período pós-contratual.

Ultrapassado esses obstáculos, mesmo que se conclua pela existência de um dever pós-eficaz específico no caso concreto, duvida há com relação à natureza jurídica da responsabilidade pelo seu descumprimento. Seria contratual ou delitual? Subjetiva, objetiva ou por culpa presumida? A parte poderá pleitear apenas perdas e danos ou também a cessação da atividade? Quiçá estes sejam os pontos de maior debate doutrina sobre o tema.

Os defensores da responsabilidade delitual, fundamentam que os deveres laterais decorrem diretamente do comando normativo da boa-fé e não do regulamento contratual. Para esta linha de pensamento, as normas contratuais apenas surgem por meio da manifestação de vontade das partes, sendo, igualmente, limitado por essa. Com efeito, as partes apenas se vinculariam nos estreitos limites da vontade declarada, sob pena de ofensa ao princípio da autonomia privada.

Por outro lado, a corrente que defende a natureza contratual, reconhece que a noção de responsabilidade, nestes casos, liga-se à doutrina de violação positiva do contrato de Hermann Staub. Advogam que adoção desta teoria, possível no ordenamento jurídico brasileiro, expandiu a noção de adimplemento, passando a abarcar as hipóteses de culpa post pactum finitum.

\footnotetext{
${ }^{5}$ MENEZES CORDEIRO, António Manuel da Rocha e. Da pós-eficácia das obrigações, cit., p. 149. ${ }^{6}$ DONNINI, Rogério. Responsabilidade civil pós-contratual: no direito civil, no direito do consumidor, no direito do trabalho, no direito ambiental e no direito administrativo. 3. ed. São Paulo: Saraiva, 2011. p. 132-133.
} 
Apesar da dificuldade da doutrina em atribuir a natureza da responsabilidade, esta corrente de pensamento entende ser o regime contratual é o mais propenso a responder à preocupação de não alterar as previsões legítimas das partes ${ }^{7}$. Vinculada a responsabilidade ao regime contratual, os danos somente adviram se relacionados ao objeto do contrato ou à expectativa criada no parceiro contratual, o que reduziria as incertezas.

Evidente, portanto, a divergência doutrinária, que confirma a necessidade de clarificar os limites que permeiam a incidência dos deveres laterais de conduta decorrentes do princípio da boa-fé objetiva.

Para a análise crítica de qual modelo melhor se adequa ao ordenamento jurídico brasileiro, no capítulo IV se imiscuir-se-á sobre os contornos da responsabilidade civil delitual e contratual - aquela, com fulcro no nenimem laedere; esta baseada no inadimplemento - bem como sobre as bases da teoria do violação positiva do contrato de Hermann Staub. Assim, se concluirá se a culpa post pactum finitum se adequa a algum dos sistemas, ou se se trata de uma terceira via da responsabilidade civil.

Também se verifica divergências doutrinárias com relação aos danos e às possíveis ações que possam ser adotadas pelo prejudicado. Com a conduta que viola o programa contratual na fase pós-contratual, surgiria a possibilidade do prejudicado pleitear o cumprimento do dever lateral através de ação cominatória, ou apenas indenização pelos prejuízos sofridos em razão da violação? Caso a ofensa não acarrete danos, pela jurisprudência do Colendo Superior Tribunal de Justiça não seria possível a condenação fundamentada exclusivamente na função punitiva. Então, nessa hipótese, nada se poderia fazer contra a violação?

Vê-se, portanto, que o ato de impor deveres não previstos expressamente, especialmente em momento posterior ao cumprimento da prestação principal, suscita diversas indagações quanto à identificação do exato momento dito pós-contratual; ao fundamento de criação ou manutenção desses deveres, à sua natureza jurídica; à quantificação dos danos e suas consequências.

Esses são os pontos que se pretendem enfrentar nesta dissertação, expondo, sempre que possível, a posição hodierna dos Tribunais pátrios sobre o instituto da culpa post pactum finitum.

\footnotetext{
${ }^{7}$ JABBOUR, Rita. La bonne foi dans l'exécution du contrat. Paris: Librairie Générale de Droit et de Jurisprudence - L.G.D.J, 2016. p. 396. (Bibliothèque de droit privé; t. 573).
} 
Busca-se, assim, estabelecer um conceito suficientemente preciso - mas não exaustivo dada a dinamicidade do conceito de boa-fé - sobre a responsabilidade civil póscontratual. Somente assim será possível dar ao sistema a segurança jurídica necessária para relações contratuais hodiernas. 


\section{CONCLUSÕES}

Realizado o estudo dos aspectos teóricos e práticos da culpa post pactum finitum, é possível realizar algumas conclusões. Como pôde notar o leitor mais arguto, no curso do caminho até aqui percorrido já foram positivadas, ao longo do texto, algumas conclusões parciais, na medida em que ia se avançando na matéria.

Para finalizar esta dissertação, cumpre, agora, reunir de forma sintética as conclusões obtidas por meio desses estudos, com a finalidade de apresentar ao leitor os contornos que se entendem adequados para a culpa post pactum finitum.

Como se observou, com o paradigma do sistema aberto, atraiu-se para o campo do direito, valores que antes eram relegados a outras ciências. Esse movimento foi facilitado com a técnica legislativa das cláusulas gerais que, por possuírem hipótese legal de grande generalidade, abrangem e submetem à tratamento jurídico todo um domínio de fatos, com a possibilidade de ajustamento das consequências ao caso concreto.

Essa mudança de paradigma também afetou o direito das obrigações. Há muito deixou de ser compreendida como mera relação de crédito e débito, passando a representar um processo dinâmico dirigido à realização do fim comum almejado pelas partes. Abrange direitos, inclusive os formativos; pretensões e ações; deveres; exceções e posições jurídicas, de modo que não se limita, apenas, ao cumprimento da prestação principal, mas sim a um conjunto de atividades necessárias à satisfação do interesse do credor.

Identificou-se, ainda, após o exame dos estudos de Staub e H. Stoll, que o vínculo obrigacional compreende dois interesses: os voltados ao cumprimento da prestação (interesses de prestação); e os orientados à proteção da pessoa e do patrimônio dos contratantes (interesses de proteção). Essa definição terá relevância especial na definição das consequências da culpa post pactum finitum.

Com base nas premissas acima, concluiu-se que os elementos essenciais da obrigação são definidos pela manifestação de vontade, sem a qual não há se falar em contrato. Porém o mero cumprimento formal da prestação pode não acarretar a satisfação do interesse de prestação. Assim, são chamadas a intervir as fontes heterônomas. Por meio delas, impõemse deveres que devem ser observados pelas partes, com o desiderato de preservar a vontade manifestada e permitir a realização da operação econômica contratual. 
Para isso, jogam a favor os princípios ditos sociais: a equivalência material, a função social dos contratos e, com maior interesse para o presente trabalho, a boa-fé objetiva, os quais também participam do nascimento e desenvolvimento das obrigações.

Denota-se, portanto, que na construção do regulamento obrigacional a fonte autônoma (declaração de vontade dos contraentes) não atua isoladamente, havendo igualmente a ação de fontes heterônomas, as quais se prestam a atenuar ou suplementar a autonomia privada.

Estas podem ser, em sua relação com a manifestação de vontade, cogentes (mandatory rules), dispositivas (permissive rules) ou supletivas (gap fillers). Dividem-se, ainda, quanto a forma como se operacionalizam, em normas rígidas ou vagas; esta, como gênero que congrega, como uma de suas espécies, as cláusulas gerais.

Dessa análise, percebe-se que o regulamento contratual é composto por cláusulas expressas (express terms) e implícitas (implied terms). As primeiras decorrem da própria manifestação de vontade. Por sua vez, através de processos interpretativos, obtém-se os termos implícitos (ou implied-in-fact). Podem ainda decorrer do reconhecimento judicial quanto à sua existência, independentemente de cláusula expressa e, nesses casos, são seriam termos supletivos (ou implied-in-law ou constructive terms)

Um importante termo contratual implícito, mesmo no sistema da common law é o dever de atuar conforme a boa-fé (duty of good faith and fair dealing). Similar é a situação do direito brasileiro, cujo princípio da boa-fé objetiva governa a atuação durante o programa contratual, e cuja incidência não pode ser afastada.

Para compreender o atuar da boa-fé objetiva na relação obrigacional, no capítulo II fez-se um breve resumo de sua evolução. Procurou-se demonstrar que a bona fidei dos romanos, unificada e absorvida como elemento da vontade no direito francês, teve sorte diversa no território tedesco, encontrando seu fundamento nos ideais da cavalaria como fonte indutora de deveres com o outro.

Assim, na definicação de sua vertente material pelo prisma negativo, afastou-se do mero sentimento de justiça do julgador ou da equidade. Concluiu-se, sob um prisma positivo, que seu fundamento está na tutela da confiança legítima e na primazia da materialidade da relação jurídica subjacente, suplantando o formalismo puro que ignora os objetivos perseguidos pelos particulares. 
O Código Civil de 2002, em seu artigo 422, dispôs sobre o dever dos contratantes de observarem a cláusula geral da boa-fé objetiva, permitindo o reenvio do magistrado a valores extra-sistemáticos e possibilitando uma aproximação do direito com a ética, com vistas a concretização do programa obrigacional desenhado pela autonomia privada.

Para tanto, tem-se reconhecido três funções ao princípio da boa-fé objetiva. A primeira, como limite ao exercício de direitos subjetivos (função corretiva), apesar de não possuir íntima relação com o presente trabalho, permitiu, através de seu estudo, reforçar o papel de tutela da confiança exercida pela boa-fé objetiva.

É funcionalizado, ainda, como critério de interpretação e concreção dos negócios jurídicos (adjuvandi ou função interpretativa). Busca-se, inicialmente, descobrir a intenção comum que se revelou no ajuste. A melhor expressão da boa-fé objetiva consiste em manter o significado que as partes deram às cláusulas no momento da contratação. Não sendo possível, impõe-se uma interpretação objetiva, considerando o significado que o comportamento leal aponte ser o mais razoável.

Ainda na função interpretativa, a boa-fé é utilizada para a colmatação de lacunas, no que se denominou "interpretação-integrativa", suprindo cláusulas que, de ordinário, constariam na avença. Dessa atividade, como se concluiu parcialmente no texto, resultarão deveres secundários.

Contudo, isso não se confunde com a função supletiva, na qual a boa-fé objetiva atua como fonte de deveres laterais conduta (supplendi). Nesta função a boa-fé não preenche partes omissas do regulamento, mas impõe deveres de conduta, independentemente de qualquer previsão. Tais deveres já integram o contrato desde logo e sendo apenas revelados. Dada a sua heterogeneidade, costuma-se subdividi-los em deveres de informação, esclarecimento e proteção da integridade física e patrimônio dos contratantes.

É possível, desta feita, concluir que a complexidade intra-obrigacional, em um primeiro nível, compreende a prestação principal, que corresponde à relação paradigmática entre crédito e débito. Neste nível, existem ainda outros deveres, denominados secundários, os quais são oriundos da própria obrigação, mas como resultado de operações de interpretação.

Em um segundo nível, estão os deveres laterais (cuja nomenclatura não é uniforme na doutrina e jurisprudência), estabelecidos à luz da circunstancias existentes e variando de intensidade conforme a espécie de relação jurídica existente. Estes deveres podem se radicar 
no interesse de prestação, servindo ao cumprimento satisfatório; ou no interesse de proteção, visando a tutela da integridade física, das vantagens contratuais e do patrimônio dos contratantes.

Certo, ainda, que a incidência do princípio da boa-fé, mormente em sua função supletiva, não é limitada à fase de conclusão e execução do contrato. Até mesmo no momento posterior à satisfação do interesse de prestação as partes continuam devendo respeito a eles. E, justamente por surgirem, ou simplesmente continuarem exigíveis, após o término da relação contratual, são denominados pós-eficazes.

Como foi possível concluir no Capítulo III, para identificação do período póscontratual é necessário que o contrato exista e produza, ao menos, algum efeito. Assim, estão fora do âmbito da culpa post pactum finitum os casos de nulidade e a anulabilidade em que a decretação opera efeitos retroativos, porque há a desconstrução da própria fonte da obrigação, que deixa de regular a relação entre as partes.

Após o estudo das demais formas extintivas, identificou-se a fase pós-contratual: o contrato existia e era válido; produziu efeitos, com a satisfação do interesse de prestação, e não ocorreu a prorrogação da relação contratual.

Começa assim, potencialmente, o período pós-contratual, no qual a ofensa aos deveres laterais pode ocasionar a responsabilização civil por culpa post pactum finitum. Nota-se, portanto, que, mesmo na fase dita pós-contratual, os antigos contratantes não podem atuar como se fossem estranhos. Devem aguardar certos deveres, de modo a não frustrar os fins contratuais.

O desenvolvimento da culpa post pactum finitum não proveio do exame doutrinário ou tampouco do reconhecimento legislativo, cuja maioria dos ordenamentos jurídicos não possuem dispositivos que a consagrem, mas sim da necessidade da jurisprudência dar soluções às lides que lhes foram submetidas.

Por essa razão, em um momento inicial, houve certa divergência de fundamentos, o que dificultou sistematização e a compreensão do instituto. Contudo, aprofundado o estudo doutrinário, foi possível definir que a culpa post pactum finitum não possui seu fundamento na expressa previsão legal; na analogia; ou na natureza específica de algumas relações.

A expressa previsão legal dará origem a pós-eficácia aparente. Diz-se aparente porque, na verdade não há pós-eficácia, mas sim eficácia atual da regra legal que a impõe expressamente. 
A analogia também se mostrou inadequada posto que os fundamento dos efeitos legalmente previstos, para o momento posterior à extinção do contrato, são diversos, impedindo a extração de uma razão comum.

Tampouco a natureza jurídica de determinadas relações fundamenta a culpa post pactum finitum. Isto porque, como se observou, as relações analisadas, em especial familiares e de trabalho, possuem características próprias que impedem sua expansão para todo o campo das obrigações. Verificou-se, ainda, que nem toda manifestação após o término na relação pode ser enquadrada na culpa post pactum finitum.

Além da pós-eficácia aparente se identificou, também, as noções de pós-eficácia virtual e continuada. A primeira consiste em deveres secundários (previstos ou extraídos de processos interpretativos - função interpretativa da boa-fé), que apenas podem ser cumpridos após a extinção da prestação principal. Já na pós-eficácia continuada, o dever secundário era exigível durante a fase de execução, porém, permanece eficaz mesmo depois do cumprimento do dever de prestar.

Tais situações não se confundem com a culpa post pactum finitum, que insere-se na pós-eficácia em sentido estrito. Esta possui seu fundamento no princípio da boa-fé objetiva, como forma de tutela da confiança e da primazia da relação material subjacente. Por meio da promessa realizada no contrato (tutela da confiança), emergem deveres laterais para as partes, com a finalidade de alcançar o projeto contratual (primazia da relação subjacente), afastando cumprimentos meramente formais. Por tais razões, impõe-se a manutenção de alguns desses deveres para o período pós-contratual, como forma de tutelar as vantagens obtidas, a pessoa e o patrimônio dos antigos parceiros contratuais.

Concluiu-se, em contrariedade com alguns autores, que tanto os deveres laterais radicados no interesse de prestação, como os radicados no interesse de proteção podem dar azo à responsabilidade civil pós-contratual, os diferiram apenas nas consequências possíveis.

Verificou-se também que alguns autores elencam, além da boa-fé objetiva, outros fundamentos adicionais para a culpa post pactum finitum. Tratam-se dos princípios constitucionais da dignidade da pessoa humana, solidariedade, igualdade e justiça social. Malgrado não haja nenhuma incoerência em sua adoção, entende-se melhor a subsunção direta ao princípio da boa-fé objetiva, até como forma de sistematizar a matéria.

$\mathrm{Na}$ definição de sua natureza jurídica, foi necessário distinguir os conceitos de responsabilidade civil contratual e extracontratual, cujo tratamento legislativo é diverso (em 
especial com relação a gradação da culpa e sua presunção, capacidade do agente, solidariedade, prescrição, cláusulas de limitação ou exoneração de responsabilidade e competência).

Examinadas as hipóteses inseridas em cada uma dessas espécies, percebeu-se que a distinção entre elas reside na qualidade do dever violado. Na responsabilidade contratual, há a violação de um direito subjetivo relativo, inerente às partes integrantes do contrato. Já na responsabilidade civil extracontratual viola-se um dever absoluto, imposto a todas as pessoas. Essa diferença é refletida, inclusive, no dever de indenizar. Na extracontratual, o dever nasce com a violação; na contratual, o dever primário de prestação será convertido em deveres secundários com prestações autônomas de restituição e indenização, fundamentados na relação jurídica preexistente.

E, eventuais limitações a autonomia privada, com a imposição ou restrição de cláusulas, não tem o condão de alterar tais conclusões, posto que a lei sempre faz da vontade das partes a base dos contratos.

Estabelecida essa diferença, identificou-se, ainda, que o campo de atuação da responsabilidade contratual é definido. $\mathrm{O}$ que não está nele, pertence à responsabilidade extracontratual. Ocorre que o adimplemento satisfatório não consiste no simples cumprimento formal da obrigação; há imposição de condutas para satisfação da finalidade negocial.

Nessa ordem de ideias, estudando o conceito de inadimplemento lato sensu no ordenamento jurídico brasileiro, concluiu-se, em virtude de uma lacuna conceitual, que é possível a assimilação da doutrina da violação positiva do contrato, que diz respeito ao descumprimento de deveres laterais que afetam apenas os interesses de proteção.

Dessa feita, o gênero inadimplemento abarca o inadimplemento absoluto (ou em sentido estrito), a mora e a violação positiva do contrato.

Apontadas tais conclusões, a dissertação perscrutou a natureza jurídica da responsabilidade civil pós-contratual. Como visto, os defensores da natureza jurídica extracontratual fundamentam que os deveres laterais decorrem diretamente do comando normativo da boa-fé e não do regulamento contratual, o qual é formado apenas pela manifestação de vontade das partes, ainda que na atividade de colmatação de lacunas. Com efeito, os deveres laterais seriam externos ao contrato. 
Contudo, o que se verificou na dissertação é que a opção pela natureza contratual da responsabilidade é natural e necessária. Isto porque, admitida a complexidade intraobrigacional, não há como se negar que ela é composta por deveres principais, secundários e laterais (de vinculação mediata ou imediata com a prestação).

Logo, denota-se que os deveres laterais, apesar de impostos pela boa-fé, integram a relação contratual, inclusive servindo de meio para que se atinja o adimplemento satisfatório. Essa internalidade dificulta afastá-los da responsabilidade contratual.

O fato de serem estabelecidos, em especial os pós-eficazes, em função do contrato anterior, reforça essa conclusão, diferenciando-o do dever geral de não lesar outrem. Caso não existisse o contrato anterior, não seria possível falar-se em pós-eficácia. Em verdade, sequer os deveres laterais pós-eficazes e os casos de reconhecimento da culpa post pactum finitum se configurariam.

Isto posto, em virtude da essencialidade de um vínculo anterior, que também é o ponto de diferenciação entre as espécies de responsabilidade, natureza jurídica contratual impõe-se naturalmente.

Concluiu-se, ainda, que a adoção da responsabilidade contratual é necessária. Isto porque, o vinculo com o contrato anterior serve de limite para a indenização, mormente nos ordenamentos jurídicos em que esta é limitada aos danos previsíveis, no inadimplemento contratual culposo.

Identificou-se, outrossim, que a responsabilidade contratual, também concede maiores vantagens para o lesado, que necessita demonstrar tão somente o dever descumprido. Soluciona de melhor maneira, também, a questão da exceção do contrato não cumprido, permitindo a retenção do pagamento, bem como afasta a possibilidade de pleitearse indenização por pequenas falhas que não comprometem o programa contratual (na extracontratual, recorde-se vige o in lege aquilia et levissima culpa venit).

Essa opção também não é incompatível com a culpa in contrahendo, porquanto, nesta busca-se o retorno à situação que estaria o lesado se não tivesse confiado (interesse negativo), de modo que basta o contato das partes, sendo despiciendo qualquer vínculo. Aliás, as hipóteses de contratos nulos são subsumidas nesta espécie. Mas diferente é a situação da culpa post pactum finitum, que não prescinde do vínculo anterior. Somente com a existência e produção de efeitos deste, é que ela poderá se configurar, de modo que não é de se estranhar que possuam natureza diversa. 
Refutou-se, além disso, a existência de uma terceira via de responsabilidade civil, a qual não constituiria outra coisa, senão uma amálgama das anteriores, não adequadamente definida.

Por fim, identificados os contornos essenciais e sua natureza jurídica, passou ao exame das possíveis consequências pela violação de deveres laterais pós-eficazes. A primeira conclusão extraída é que o grau de vinculação do dever lateral pós-eficaz com o interesse de prestação tem significativa influência nas possíveis consequências a serem adotadas.

Havendo uma relação imediata, o descumprimento desses deveres afetará a própria prestação, de modo que incidirão as regras gerais inerentes ao inadimplemento absoluto e a mora. É o caso da concessão comercial, em que o descumprimento de dever lateral ensejou a resolução contratual. Malgrado o contrato admita alguma alteração unilateral da área de exclusividade e supressão de produtos, tais ações somente podem ser admitidas se não inviabilizarem a obtenção do interesse de prestação. Com a violação deste, operou-se a resolução por inadimplemento culposo. ${ }^{888}$

Por outro lado, havendo vinculação apenas mediata com o interesse de prestação, os deveres laterais estarão, portanto, radicados no interesse de proteção, dando azo à violação positiva do contrato. Aqui, não sendo afetada a prestação principal, a consequência será, via de regra, indenizatória. Foi o que ocorreu no caso da "vista eterna" 889 , no qual a construtora/vendedora foi condenada a indenizar a compradora pela perda da vista.

Contudo, é possível a fixação de consequências diversas, como a paralisação de um direito (no caso do contrato de edição) ou a possibilidade de retenção do pagamento (no julgado referente ao caso do carpete). ${ }^{890}$

Nota-se, portanto, uma escala com relação aos graus de ofensa. O descumprimento de deveres laterais pode obrigar somente à indenização dos danos, inclusive morais ou, ocorrendo a perda do interesse de prestação, acarretar a transformação da violação positiva do contrato em inadimplemento absoluto. Isto porque, como dito, não se tratam de esferas autônomas, mas sim vinculadas de alguma forma à obrigação anterior.

\footnotetext{
${ }^{888}$ BRASIL. Tribunal de Justiça do Estado de São Paulo - TJSP. 32 a Câmara de Direito Privado. Apelação Cível. Processo $n^{o}$ 9049922-42.2009.8.26.0000. Relator: Hamid Bdine. Data de Julgamento: 30/01/2014, Data de Publicação: 01/02/2014. Disponível em: https://esaj.tjsp.jus.br.

${ }^{889} \mathrm{O}$ caso é mencionado na seção 2 do capítulo III.

${ }^{890}$ Ambos os casos citados constam na seção 2, do Capítulo III desta dissertação.
} 
$\mathrm{O}$ estudo das consequências do inadimplemento dos deveres laterais pós-eficazes permite, ainda, reforçar a opção pela natureza contratual da responsabilidade por culpa post pactum finitum. 


\section{REFERÊNCIAS}

\section{Doutrina}

AGUIAR JUNIOR, Ruy Rosado de. Extinção dos contratos por incumprimento do devedor: resolução. Rio de Janeiro: Aide Editora, 2004.

ALCARO, Francesco. Diritto privato. 4. ed. Milano: Wolters Kluwer Italia, 2019.

ALPA, Guido. Trattato di diritto civile e commerciale: il contratto in generale: fonti, teorie, metodo. Milano: Dott. A. Guiffrè Editore, 2014.

ALPA, Guido. Trattato di diritto privato: i principi generali. Milano: Dott. A. Guiffrè Editore, 1993.

ALVIM, Agostinho. Da inexecução das obrigações e suas consequências. 2. ed. São Paulo: Saraiva, 1955.

AMARAL, Francisco. Direito civil: introdução. 6. ed. Rio de Janeiro: Renovar, 2006.

AMENDOEIRA JUNIOR, Sidnei. Principais características do contrato de franchising. In: BRUSCHI, Gilberto G.; COUTO, Mônica B.; SILVA, Ruth M. J. de A.; PEREIRA, Thomaz H. J. de A. (Coords.). Direito processual empresarial: estudos em homenagem ao professor Manoel de Queiroz Pereira Calças. Rio de Janeiro: Elsevier, 2012.

ANDRADE, Daniel de Pádua; PEREIRA, Fabio Queiroz. Revisitando o papel da violação positiva do contrato na teoria do inadimplemento. Scientia Iuris, revista do curso de Mestrado em Direito Negocial da UEL, Londrina, v. 22, n. 1, p. 258-282, mar. 2018. Disponível

em: http://www.uel.br/revistas/uel/index.php/iuris/article/download/30366/23357. doi: $10.5433 / 2178-8189.2018 \mathrm{v} 22 \mathrm{n} 1 \mathrm{p} 258$.

ATIYAH, P.S. An introduction to the law of contract. $3^{\text {rd }}$ ed. Oxford: Clarendon Press, 1985.

ATIYAH, P.S. The rise and fall of freedom in contract. Oxford: Clarendon Press, 1979.

AZEVEDO, Álvaro Villaça O. novo Código Civil brasileiro tramitação; função social do contrato; boa-fé objetiva; teoria da imprevisão e, em especial, onerosidade excessiva (Laesio Enormis). In: TEPEDINO, Gustavo; FACHIN, Luiz Edson (Coords.). O direito e o tempo: embates jurídicos e utopias contemporâneas. São Paulo: Renovar, 2008.

BARBOSA, Ruy. As cessões de clientela e a interdição de concorrência nas alienações de estabelecimentos comerciais e industriais. Rio de Janeiro: Ministério da Educação e Saúde, 1948. t. 1, p. XI-XXXII. (Obras Completas de Rui Barbosa; 40).

BENACCHIO, Marcelo, Responsabilidade civil contratual. São Paulo: Saraiva, 2011. (Coleção Professor Agostinho Alvim). 
BIANCA, Massimo. Diritto civile: il contratto. 2. ed. Milano: Dott. A. Giuffrè Editore, 2015. v. 3.

BIANCA, Massimo. Diritto civile: la responsabilità. 2. ed. Milano: Dott. A. Giuffrè Editore, 2012. v. 5.

BITTAR, Eduardo C. B.; ALMEIDA, Guilherme A. de. Curso de filosofia do direito. 7. ed. São Paulo: Atlas, 2009.

BONINI, Paulo R. Responsabilidade civil por ato lícito. In: GUERRA, Alexandre Dartanhan de Mello; BENACCHIO, Marcelo (Coords.), Responsabilidade civil. São Paulo: Escola Paulista de Magistratura, 2015. p. 159-181.

BRUSCHI, Gilberto G.; COUTO, Mônica B.; SILVA, Ruth M. J. de A.; PEREIRA, Thomaz H. J. de A. (Coords.). Direito processual empresarial: estudos em homenagem ao professor Manoel de Queiroz Pereira Calças. Rio de Janeiro: Elsevier, 2012.

BRUSCHI, Gilberto Gomes; COUTO, Mônica Bonetti; SILVA, Ruth Maria Junqueira de A. Pereira e; PEREIRA, Thomaz Henrique Junqueira de A. (Coords.). Direito processual empresarial: estudos em homenagem a Manoel Queiroz Pereira Calças. Rio de Janeiro: Elsevier, 2012.

BURTON, Steven J. Principles of contract law. $4^{\text {th }}$ ed. St. Paul. Minn: West Academic Publishing, 2012. (American Casebook Series).

CANARIS, Claus-Wilhelm. Direitos fundamentais e direito privado. Tradução Ingo Wolfgang Sarlet e Paulo Mota Pinto. 4. reimp. Coimbra: Almedina, 2016.

CANARIS, Claus-Wilhelm. O novo direito das obrigações na Alemanha. [Exposição gravada e revista pelo autor. XXII Congresso Internacional de Direito Comparado, realizado na EMERJ em 03-09-2003]. Revista da EMERJ, Rio de Janeiro, v. 7, n. 27, p. 108-124, $2004 . \quad$ Disponível em: http://www.emerj.tjrj.jus.br/revistaemerj_online/edicoes/revista27/revista27_108.pdf.

CASSETARI, Christiano. Multa contratual: teoria e prática da cláusula penal. 4. ed. São Paulo: Editora Revista dos Tribunais, 2013.

CASTALDELLO, Fábio L. O conceito de fato do produto ou do serviço e sua (necessária?) vinculação à ocorrência de um perigo à segurança do consumidor. In: GUERRA, Alexandre Dartanhan de Mello; MALFATTI, Alexandre David (Coords.). Reflexões de magistrados paulistas sobre os 25 anos do Código de Defesa do Consumidor. São Paulo: Escola Paulista de Magistratura, 2015.

CAVALIERI FILHO, Sérgio. Programa de responsabilidade civil. 11. ed. São Paulo: Atlas, 2014.

COELHO, Fábio Ulhoa. Curso de direito comercial: direito de empresa. 13. ed. São Paulo: Saraiva, 2012. v. 3. 
COGO, Rodrigo B. A frustração do fim do contrato: o impacto dos fatos supervenientes sobre o programa contratual. Rio de Janeiro: Renovar, 2012.

COSTA, José Eduardo. A revisão dos contratos: entre a pacta sunt servanda e o equilíbrio econômico. In: LOTUFO, Renan; NANNI, Giovanni Ettore; MARTINS, Fernando Rodrigues (Coords.). Temas relevantes de direito civil contemporâneo: reflexões sobre os 10 anos do Código Civil. São Paulo: Atlas, 2012.

COSTA, Mário Júlio de Almeida. Direito das obrigações. 12. ed. 6. reimp. Coimbra: Almedina, 2018.

CRUZ, Guilherme Ferreira. Os reflexos condicionantes da parte geral da Lei 8.078/90 na formação do direito material positivo das relações de consumo. 2011. Tese (Doutorado) Programa de Pós-Graduação em Direito da Faculdade de Direito da Universidade de São Paulo, São Paulo, 2011.

CRUZ, Guilherme Ferreira. Teoria geral das relações de consumo. São Paulo: Saraiva, 2014.

DANTAS JUNIOR, Aldemiro R. Teoria dos atos próprios no princípio da boa-fé. Curitiba: Juruá, 2008. (Série Biblioteca Arruda Alvim).

DEVIS ECHANDÍA, Hernando. Teoria general de la prueba judicial. 5. ed. Buenos Aires: Victor P. de Zavalia - Editor, 1981. t. 1.

DI PIETRO, Maria Sylvia Zanella. Direito administrativo. 28. ed. São Paulo: Atlas, 2015.

DIAS, José Aguiar. Da responsabilidade civil. 12. ed. rev. atual. de acordo com o Código Civil de 2002 e aumen. por Rui Berford Dias. Rio de Janeiro: Editora Lumen Juris, 2012.

DIGESTO ou Pandectas do Imperador Justiniano: Livros 5-11. Tradução brasileira por Manoel da Cunha Lopes e Vasconcellos. Tradução complementar, organização geral, adaptação e supervisão de transcrição por Eduardo C. Silveira Marchi, Bernardo B. Queiroz de Moraes, Dárcio R. Martins Rodrigues, Hélcio M. França Madeira. 1. ed. São Paulo: YK Editora, 2017. v. 1 e v. 2.

DONNINI, Rogério. Responsabilidade civil pós-contratual: no direito civil, no direito do consumidor, no direito do trabalho, no direito ambiental e no direito administrativo. 3. ed. São Paulo: Saraiva, 2011.

DUARTE, Nestor. In: PELUSO, Cezar (Coord.) Código Civil comentado: doutrina e jurisprudência. 8. ed. Barueri, SP: Manole, 2014.

DWORKIN, Ronald. Levando direitos a sério. Trad. Nelson Boeira. 3. ed. São Paulo: Ed. WMF Martins Fontes, 2010.

ENGISCH, Karl. Introdução ao pensamento jurídico. Tradução de J. Baptista Machado. 8. ed. Lisboa: Calouste Gulbenkian, 2001. 
FARIAS, Cristiano Chaves; ROSENVALD, Nelson; BRAGA NETTO, Felipe P. Curso de direito civil: responsabilidade civil. 5. ed. Salvador: Ed. JusPodivm, 2018. v. 3.

FISHER, Howard D. O sistema jurídico alemão e sua terminologia. Tradução de Regina Lyra. Rio de Janeiro: Forense, 2013.

FORGIONI, Paula A. Contrato de distribuição. 2. ed. São Paulo: Editora Revista dos Tribunais, 2008.

FRADA, Manuel A. Carneiro da. Teoria da confiança e responsabilidade civil. 1. ed. reimpr. Coimbra: Almedina, 2016.

FRANTZ, Laura C. Revisão dos contratos: elementos para sua construção dogmática. São Paulo: Saraiva, 2007. (Coleção Professor Agostinho Alvim).

FRATINI, Marco. Il sistema del diritto civile: le obbligazioni. 3. ed. Roma: DIKE Giuridica Editrice, 2019. v. 1.

FRIED, Charles. Contract as promise: a theory of contractual obligation. $2^{\text {nd }}$ ed. New York: Oxford University Press, 2015.

GARBI, Carlos Alberto. A intervenção judicial no contrato em face do princípio da integridade da prestação e da clausula geral da boa-fé: uma nova visão do adimplemento contratual. São Paulo: Escola Paulista da Magistratura, 2014.

GARCIA, Enéas Costa. Responsabilidade pré e pós-contratual à luz da boa-fé. São Paulo: Editora Juarez de Oliveira, 2003.

GHESTIN, Jacques. Traité de droit civil: les obligations; le contrat; formation. 2. éd. Paris: LGDJ, 1988.

GODOY, Claudio Luiz Bueno de. Código Civil e Código de Defesa do Consumidor: convergência de princípios e distinção de sua modulação: um paralelo entre os deveres que criam. In: MELGARÉ, Plínio (Org.). O direito das obrigações na contemporaneidade: estudos em homenagem ao Ministro Ruy Rosado de Aguiar Júnior. Porto Alegre: Livraria do Advogado Editora, 2014.

GODOY, Claudio Luiz Bueno de. Função social do contrato. 3. ed. São Paulo: Saraiva, 2009. (Coleção Professor Agostinho Alvim).

GODOY, Claudio Luiz Bueno de. Responsabilidade civil pelo risco da atividade. 2. ed. São Paulo: Saraiva, 2010. (Coleção Professor Agostinho Alvim).

GOMES, Orlando. Contratos. 26. ed. atual. por Antonio Junqueira de Azevedo e Francisco Paulo De Crescenzo Marino. Rio de Janeiro: Forense, 2007.

GOMES, Orlando. Obrigações. 18. ed. rev. e atual. por Edvaldo Brito. Rio de Janeiro: Forense, 2016. 
GONÇALVES, Carlos Roberto. Responsabilidade civil. 15. ed. São Paulo: Saraiva, 2014.

GUERRA, Alexandre Dartanhan de Mello; BENACCHIO, Marcelo (Coords.). Responsabilidade civil. São Paulo: Escola Paulista de Magistratura, 2015.

GUERRA, Alexandre Dartanhan de Mello; MALFATTI, Alexandre David (Coords.). Reflexões de magistrados paulistas sobre os 25 anos do Código de Defesa do Consumidor. São Paulo: Escola Paulista de Magistratura, 2015.

GUESTIN, Jacques, Traité de droit civil: les effets du contrat. 2. éd. Paris: Librairie Générale de Droit et de Jurisprudence - L.G.D.J, 1994.

GUIMARÃES, Paulo Jorge Scartezzini. Responsabilidade civil e interesse contratual positivo e negativo (em caso de descumprimento). In: GUERRA, Alexandre Dartanhan de Mello; MALFATTI, Alexandre David (Coords.) Responsabilidade civil. São Paulo: Escola Paulista de Magistratura, 2015.

HAICAL, Gustavo Luís da Cruz. O inadimplemento pelo descumprimento exclusivo do dever lateral advindo da boa-fé objetiva. Revista dos Tribunais, São Paulo, v. 99, n. 900, p. 45-84, out. 2010.

HILlMAN, Robert A. Principles of contract law. $3^{\text {rd }}$ ed. Saint Paul, MN: West Academic Publishing, 2004.

JABBOUR, Rita. La bonne foi dans l'exécution du contrat. Paris: Librairie Générale de Droit et de Jurisprudence - L.G.D.J, 2016. (Bibliothèque de droit privé; t. 573).

JALUZOT, Béatrice. La bonne foi dans les contrats: étude comparative des droit français, allemand et japonais. Paris: Ed. Dalloz, 2001. (Nouvelle Bibliothèque de thèses).

JORNADA de Direito Civil, 6. Ministro Ruy Rosado de Aguiar. Conselho da Justiça Federal. Disponível em: https://www.cjf.jus.br/enunciados/enunciado/150.

JUNQUEIRA DE AZEVEDO, Antonio. A boa fé na formação dos contratos. In: NERY JUNIOR, Nelson; NERY, Rosa M. B. B. A. (Orgs.). Responsabilidade civil: direito de obrigações e direito negocial. São Paulo: Editora Revista dos Tribunais, 2010. (Coleção Doutrinas Essenciais, v. 2).

JUNQUEIRA DE AZEVEDO, Antonio. La bonne foi dans la formation du contrat en droit brésilien. Revista da Faculdade de Direito da Universidade de São Paulo, São Paulo, v. 87, p. 91-100, jan./dez. 1992. Disponível em: https://www.revistas.usp.br/rfdusp/article/view/67169.

JUNQUEIRA DE AZEVEDO, Antonio. La bonne foi dans les relations entre particuliers (dans la formation du contrat): rapport brésilien. In: TRAVAUX de l'Association Henri Capitant: la bonne foi: journées louisianaises (14-17 mai 1992). Paris: Litec, 1994. t. 43, p. 77-84. 
JUNQUEIRA DE AZEVEDO, Antonio. Contrato de distribuição por prazo determinado com cláusula de exclusividade recíproca. Configuração de negócio jurídico per relationem na cláusula de opção de compra dos direitos do distribuidor pela fabricante e consequente restrição da respectiva eficácia. Exercício abusivo do direito de compra, equivalente a resilição unilateral, sem utilização do procedimento pactuado, com violação da boa-fé objetiva. In: JUNQUEIRA DE AZEVEDO, Antonio. Novos estudos e pareceres de direito privado. São Paulo: Saraiva, 2009.

JUNQUEIRA DE AZEVEDO, Antonio. O direito moderno e a pós-codificação. Revista da Faculdade de Direito da Universidade de São Paulo, São Paulo, v. 94, p. 3-12, 1999.

JUNQUEIRA DE AZEVEDO, Antonio. Estudos e pareceres de direito privado. São Paulo: Saraiva, 2004.

JUNQUEIRA DE AZEVEDO, Antonio. Insuficiências, deficiências e desatualização do projeto de Código Civil (atualmente, Código Aprovado) na questão da boa-fé objetiva nos contratos. In: JUNQUEIRA DE AZEVEDO, Antonio. Estudos e pareceres de direito privado. São Paulo: Saraiva, 2004.

JUNQUEIRA DE AZEVEDO, Antonio. Interpretação do contrato pelo exame da vontade contratual. O comportamento das partes posterior à celebração. Interpretação e efeitos do contrato conforme o principio da boa-fé objetiva. Impossibilidade de venire contra factum proprium e de utilização de dois pesos e duas medidas (tu quoque). Efeitos do contrato e sinalagma. A assunção pelos contratantes de riscos específicos e a impossibilidade de fugir do programa contratual estabelecido. In: JUNQUEIRA DE AZEVEDO, Antonio. Novos estudos e pareceres de direito privado. São Paulo: Saraiva, 2009.

JUNQUEIRA DE AZEVEDO, Antonio. Negócio jurídico: existência, validade e eficácia. 4. ed. 8. tir. São Paulo: Saraiva, 2002.

JUNQUEIRA DE AZEVEDO, Antonio. Novos estudos e pareceres de direito privado. São Paulo: Saraiva, 2009.

JUNQUEIRA DE AZEVEDO, Antonio. Relatório brasileiro sobre a revisão contratual apresentado para as Jornadas Brasileiras da Associação Henri Capitant. In: JUNQUEIRA DE AZEVEDO, Antonio. Novos estudos e pareceres de direito privado. São Paulo: Saraiva, 2009.

JUNQUEIRA DE AZEVEDO, Antonio. Responsabilidade pré-contratual no Código de Defesa do Consumidor: estudo comparativo com a responsabilidade pré-contratual no direito comum. In: JUNQUEIRA DE AZEVEDO, Antonio. Estudos e pareceres de direito privado. São Paulo: Saraiva, 2004.

JUNQUEIRA DE AZEVEDO, Antonio. Responsabilidade pré-contratual no Código de Defesa do Consumidor: estudo comparativo com a responsabilidade pré-contratual no direito comum. Revista da Faculdade de Direito da Universidade de São Paulo, São Paulo, v. 90, p. 121-132, 1995. 
JUNQUEIRA DE AZEVEDO, Antonio; TÔRRES, Heleno Taveira; CARBONE, Paolo (Coords.). Princípios do novo Código Civil brasileiro e outros temas: homenagem a Tullio Ascarelli. 2. ed. São Paulo: Quartier Latin, 2010.

LARENZ, Karl. Base del negocio jurídico y cumplimiento de los contratos. Traducción de Carlos Fernandez Rodriguez. Buenos Aires, AR: Editorial Olejnik, 2018. (Colección: Biblioteca de Derecho Privado).

LARENZ, Karl. Derecho de obligaciones. Traducción de Jaime Santos Briz. Madrid: Editorial Revista de Derecho Privado, 1958. t. 1.

LEITÃO, Luís Manuel Teles de Menezes. Direito das obrigações. 8. ed. Coimbra, PT: Almedina, 2009. v. 1.

LES HUISSIERS de Justice. Disponível em: https://cnhj.huissier-justice.fr.

LEWICKI, Bruno. Panorama da boa-fé objetiva. In: TEPEDINO, Gustavo (Org.). Problemas de direito civil-constitucional. 3. ed. Rio de Janeiro: Renovar, 2001. p. 55-76.

LOTUFO, Renan; NANNI, Giovanni Ettore; MARTINS, Fernando Rodrigues (Coords.). Temas relevantes de direito civil contemporâneo: reflexões sobre os 10 anos do Código Civil. São Paulo: Atlas, 2012.

MALAURIE, Philippe; AYNÈS, Laurent; STOFFEL-MUNCK, Philippe. Droit des obligations. 8. éd. Paris: Librairie Générale de Droit et de Jurisprudence - L.G.D.J, 2016. (Collection Droit Civil).

MARCHI, Eduardo C. Silveira. Guia de metodologia jurídica: teses, monografias e artigos. 3. ed. São Paulo: YK Editora, 2017.

MARQUES, Cláudia Lima; BENJAMIN, Antonio Herman V.; MIRAGEM, Bruno. Comentários ao Código de Defesa do Consumidor. 4. ed. rev. atual. e ampl. São Paulo: Editora Revista dos Tribunais, 2013.

MARQUES, Cláudia Lima; MIRAGEM, Bruno (Orgs.). Direito do consumidor: contratos de consumo. São Paulo: Editora Revista dos Tribunais, 2011. (Coleção Doutrinas Essenciais; v. 4).

MARTINS-COSTA, Judith A boa-fé no direito privado: critérios para a sua aplicação. 2. ed. São Paulo: Saraiva, 2018.

MARTINS-COSTA, Judith. A boa-fé no direito privado: sistema e tópica no processo obrigacional. 1. ed. 2. tir. São Paulo: Editora Revista dos Tribunais, 2000.

MARTINS-COSTA, Judith; FRADERA, Véra J. (Orgs.). Estudos de direito privado e processual civil em homenagem a Clóvis do Couto e Silva. São Paulo: Editora Revista dos Tribunais, 2014. 
MARTINS-COSTA, Judith (Org.). A reconstrução do direito privado: reflexos dos princípios, diretrizes e direitos fundamentais constitucionais no direito privado. São Paulo: Editora Revista dos Tribunais, 2002.

MASCARO, Alysson Leandro. Filosofia do direito. 3. ed. São Paulo: Atlas, 2013.

MAZEAUD, Henri; MAZEAUD, Léon; TUNC, André. Tratado Teórico y práctico de la responsabilidad civil delictual y contractual. Traducción de Luis Alcalá-Zamora y Castillo. 5. ed. Buenos Aires: Ediciones Jurídicas Europa-América, 1962. t. 1, v. 2.

MELO, Diogo L. Machado de. Culpa extracontratual. São Paulo: Saraiva, 2013 (Coleção Professor Agostinho Alvim).

MELO, Diogo L. Machado de. Notas sobre a responsabilidade civil pós-contratual. In: NANNI, Giovanni Ettore (Coord.). Temas relevantes do direito civil contemporâneo: reflexões sobre os cinco anos do Código Civil: estudos em homenagem ao professor Renan Lotufo. São Paulo: Atlas, 2008. p. 400-442.

MENEZES CORDEIRO, António Manuel da Rocha e. Da boa-fé no direito civil. 6. reimpr. Coimbra: Almedina, 2015.

MENEZES CORDEIRO, António Manuel da Rocha e. Da pós-eficácia das obrigações. In: MENEZES CORDEIRO, António Manuel da Rocha e. Estudos de direito civil. Coimbra: Almedina, 1987. v. 1.

MENEZES CORDEIRO, António Manuel da Rocha e. Estudos de direito civil. Coimbra: Almedina, 1987. v. 1.

MENEZES CORDEIRO, António Manuel da Rocha e. Tratado de direito civil: direito das obrigações. 2. ed. Coimbra: Almedina, 2016. v. 9.

MENEZES CORDEIRO, António Manuel da Rocha e. Tratado de direito civil: parte geral - negócio jurídico, formação, conteúdo e interpretação, vícios da vontade, ineficácia e invalidades. 4. ed. Coimbra: Almedina, 2014. v. 2.

MENEZES CORDEIRO, António Manuel da Rocha e. Tratado de direito civil: parte geral. 2. ed. Coimbra: Almedina, 2015. v. 10.

MENEZES CORDEIRO, António Manuel da Rocha e. Violação positiva do contrato. In: MENEZES CORDEIRO, António Manuel da Rocha e. Estudos de direito civil. Coimbra: Almedina, 1987.

MIRANDA, Francisco Cavalcanti Pontes de. Tratado de direito privado: parte especial: direito das Obrigações. Atualizado por Nelson Nery Jr. e Rosa Maria de Andrade Nery. 2. tir. São Paulo: Editora Revista dos Tribunais, 2012. t. 22.

MORAIS, Ezequiel; PODESTÁ, Fábio Henrique; CARAZAI, Marcos Marins. Código de Defesa do Consumidor comentado de acordo de com o CPC/2015. 2. ed. São Paulo: Quartier Latin, 2017. 
MORSELLO, Marco Fábio. Contratos existenciais e de lucro: análise sob a ótica dos princípios contratuais contemporâneos. In: LOTUFO, Renan; NANNI, Giovanni Ettore; MARTINS, Fernando Rodrigues (Coords.). Temas relevantes de direito civil contemporâneo: reflexões sobre os 10 anos do Código Civil. São Paulo: Atlas, 2012.

MOTA, Maurício J. P. A pós-eficácia das obrigações. In: TEPEDINO, Gustavo (Org.). Problemas de direito civil-constitucional. 3. ed. Rio de Janeiro: Renovar, 2001.

MOTA, Maurício J. P. Responsabilidade civil pós-contratual. In: SIMÃO, José Fernando; BELTRÃO, Silvio R. (Coords.). Direito civil: estudos em homenagem a José de Oliveira Ascensão: direito privado. São Paulo: Atlas, 2015. v. 2.

MOZOS, José Luis de los. Principio de la buena fe: sus aplicaciones prácticas en el derecho civil español. Barcelona: Bosch, 1965.

NANNI, Giovanni Ettore (Coord.). Comentários ao Código Civil: direito privado contemporâneo. São Paulo: Saraiva Educação, 2018.

NANNI, Giovanni Ettore (Coord.). Temas relevantes do direito civil contemporâneo: reflexões sobre os cinco anos do Código Civil: estudos em homenagem ao professor Renan Lotufo. São Paulo: Atlas, 2008.

NEGREIROS, Tereza. Fundamentos para uma interpretação constitucional do princípio da boa-fé. Rio de Janeiro: Renovar, 1998.

NERY JUNIOR, Nelson. Código Civil comentado. 4. ed. São Paulo: Editora Revista dos Tribunais, 2006.

NEVES, Julio Gonzaga Andrade. A Suppressio (Verwirkung) no direito civil. São Paulo: Almedina, 2016.

NITSCHKE, Guilherme. Lacunas contratuais e interpretação: história, conceito e método. São Paulo: Quartier Latin, 2019.

NORDMEIER, Carl Friedrich. O novo direito das obrigações no Código Civil alemão: a reforma de 2002. Revista Cadernos do Programa de Pós-Graduação em Direito PPGDir./UFRGS, Porto Alegre, n. 1, p. 203-236, mar. 2004. Disponível em: https://seer.ufrgs.br/ppgdir/article/view/43502/27380.

NORONHA, Fernando. O direito dos contratos e seus princípios fundamentais: autonomia privada, boa-fé, justiça contratual. São Paulo: Saraiva, 1994.

NUNES, Luiz Antônio Rizzatto. Comentários ao Código de Defesa do Consumidor. 8. ed. São Paulo: Saraiva, 2015.

NUNES, Luiz Antônio Rizzatto. Manual de introdução ao estudo do direito. 15. ed. São Paulo: Saraiva, 2018.

PELUSO, Cezar (Coord.). Código Civil comentado: doutrina e jurisprudência. 8. ed. Barueri, SP: Manole, 2014. 
PEREIRA, Caio Mário da Silva. Instituições de direito civil: contratos. Declarações de vontade. Responsabilidade civil. Rio de Janeiro: Forense, 2007. v. 3.

PERLINGIERI, Pietro. Codice Civile annotato con la dottrina e la giurisprenza. Napoli: Edizioni Scientifiche Italiane, 1991. t. 1, Libro quarto.

PERLINGIERI, Pietro. Perfis do direito civil: introdução ao direito civil constitutional. Tradução de Maria Cristina De Cicco. 3. ed. Rio de Janeiro: Renovar, 2002.

PINTO, Agerson Tabosa. Da representação política no governo da roma antiga. Revista Latino-Americana de Estudos Constitucionais, Belo Horizonte, n. 6, p. 409-438, jul./dez. 2005.

PINTO, Carlos Alberto da Mota. Cessão da posição contratual. Reimpr. Coimbra: Almedina, 2003.

POTHIER, Robert Joseph. Tratado das obrigações. Tradução de Adrian Soterro de Witt Batista e Douglas Dias Ferreira. Campinas, SP: Servanda, 2002.

RANOUIL, Véronique. L'autonomie de la volonté. Paris: Presses Universitaire de France, 1980.

REALE, Miguel. Lições preliminares de direito. 27. ed. São Paulo: Saraiva, 2002.

REALE, Miguel. Questões de direito privado. São Paulo: Saraiva, 1997.

RODRIGUES JUNIOR, Otávio Luiz. Revisão judicial dos contratos: autonomia da vontade e teoria da imprevisão. 2. ed. São Paulo: Atlas, 2006.

RODRIGUES JUNIOR, Otávio Luiz; RODAS, Sérgio. Interview with Reinhard Zimermman and Jan Peter Schmidt / Entrevista com Reinhard Zimmermann e Jan Peter Schmidt. Revista de Direito Civil Contemporâneo, São Paulo, v. 4, p. 379-413, 2015. Disponível em: http://www.direitocontemporaneo.com/?page_id=2.

ROHWER, Claude D; SKROCKI, Anthony M.; MALLOY, Michael P. Contracts in a nutshell. $8^{\text {th }}$ ed. St. Paul, MN: West Academic Publishing, 2017.

ROPPO, Enzo. O contrato. Tradução de Ana Coimbra e M. Januário C. Gomes. Coimbra: Almedina, 2009.

ROPPO, Vicenzo. Il contratto. 2. ed. Milano: Giuffrè Editore, 2011.

ROSENVALD, Nelson. As funções da responsabilidade civil: a reparação e a pena civil. 2. ed. São Paulo: Atlas, 2014.

SARLET, Ingo Wolfgang. A eficácia dos direitos fundamentais. Porto Alegre: Livraria do Advogado, 1998. 
SAVATIER, René. Traité de la responsabilité civile en droit français civil, administratif, professionel, procédural. 2. ed. Paris: Librairie Générale de Droit et de Jurisprudence L.G.D.J, 1951. t. 1 e t. 2.

SCAFF, Fernando Campos. Aspectos fundamentais da empresa agrária. São Paulo: Malheiros, 1997.

SCAFF, Fernando Campos. Direito à saúde no âmbito privado: contratos de adesão, planos de saúde e seguro-saúde. São Paulo: Saraiva, 2010. (Edição Digital). PUB. ISBN 9788502114111.

SCAFF, Fernando Campos. A função social dos imóveis agrários. Revista dos Tribunais, São Paulo, v. 94, n. 840, p. 107-113. out. 2005.

SCAFF, Fernando Campos. A iatrogenia e o nexo causal na responsabilidade civil. In: LOPEZ, Teresa Ancona; LEMOS, Patrícia Faga Iglecias; RODRIGUES JR., Otavio Luiz (Orgs.). Sociedade de risco e direito privado: desafios normativos, consumeristas e ambientais. 1. ed. São Paulo: Atlas, 2013. p. 186-192.

SCAFF, Fernando Campos. As novas figuras contratuais e a autonomia da vontade. Revista da Faculdade de Direito da Universidade de São Paulo, São Paulo, v. 91, p. 141-159, jan./dez. 1996.

SCAFF, Fernando Campos. As relações jurídicas privadas no direito à saúde. Tese (Livre Docência) - Faculdade de Direito da Universidade de São Paulo, USP, 2007.

SCAFF, Fernando Campos. A responsabilidade do empresário pelo fato do produto e do serviço, do Código Civil ao Código de Proteção e Defesa do Consumidor. Revista dos Tribunais, São Paulo, v. 86, n. 737, p. 23-33, mar. 1997.

SCAFF, Fernando Campos. Teoria geral do estabelecimento agrário. São Paulo: Editora Revista dos Tribunais, 2001.

SCHREIBER, Anderson. Novos paradigmas da responsabilidade civil: da erosão dos filtros da reparação à diluição dos danos. 6. ed. São Paulo: Atlas, 2015.

SCHREIBER, Anderson. A proibição de comportamento contraditório: tutela da confiança e venire contra factum proprium. 4. ed. rev. e atual. São Paulo: Atlas, 2016.

SEIBT-FOMBART, Fabiola Oliveira. Les relations post-contractuelles. Memoire pour le Diplome d'Études Approfondis. Strasbourg: Faculté de Droit. Université Robert Schuman de Strasbourg, 2002. Disponível em: http://www-cde.ustrasbg.fr/da/da/AnnexesMemoires/Promo2002/seibt.pdf.

SILVA, Clóvis do Couto e. A obrigação como processo. Reimpr. Rio de Janeiro: Editora FGV, 2006.

SILVA, Jorge Cesa Ferreira da. A boa-fé e a violação positiva do contrato. Rio de Janeiro: Renovar, 2002. (Biblioteca de teses). 
SILVA, José Afonso da. Curso de direito constitucional positivo. 37. ed. São Paulo: Malheiros, 2014.

SILVA, Luís Renato Ferreira da. Revisão dos contratos no Código Civil: reflexões para uma sistematização das suas causas à luz da intenção comum dos contratantes. In: LOTUFO, Renan; NANNI, Giovanni Ettore; MARTINS, Fernando Rodrigues (Coords.). Temas relevantes de direito civil contemporâneo: reflexões sobre os 10 anos do Código Civil. São Paulo: Atlas, 2012. p. 380-382.

SIMÃO, José Fernando; BELTRÃO, Silvio R. (Coords.). Direito civil: estudos em homenagem a José de Oliveira Ascensão: direito privado. São Paulo: Atlas, 2015. v. 2.

SOMBRA, Thiago Luís Santos. Adimplemento contratual e cooperação do credor. São Paulo: Saraiva, 2011. (Coleção Professor Agostinho Alvim).

STAUB, Hermann. Le violazioni positive del contratto (Die positiven vertragsverletzungen). Trad. it. di Giovanni Varanese. Napoli: Edizioni Scientifiche Italiane, 2001.

STEINER, Renata C. Reparação de danos: interesse positivo e interesse negativo. São Paulo: Quartier Latin, 2018.

TEPEDINO, Gustavo. Temas de direito civil. 3. ed. Rio de Janeiro: Renovar, 2004.

TEPEDINO, Gustavo (Org.). Problemas de direito civil-constitucional. 3. ed. Rio de Janeiro: Renovar, 2001.

TEPEDINO, Gustavo; FACHIN, Luiz Edson (Coords.). O direito e o tempo: embates jurídicos e utopias contemporâneas. São Paulo: Renovar, 2008.

TREVISAN, Marco Antônio Responsabilidade civil pós-contratual. Revista de Direito Privado, São Paulo, v. 4, n. 16, p. 199-215, out./dez. 2003.

UDA, Giovanni Maria. La buona fede nell'esecuzione del contrato. Torino: G. Giappichelli Editore, 2004.

VARELA, João de M. Antunes. Das obrigações em geral. 10. ed. 15. reimp. Coimbra: Almedina, 2018. v. 1 e v. 2.

VARELA, João de M. Antunes. Das obrigações em geral. 7. ed. 12. reimp. Coimbra: Almedina, 2017. v. 2.

VINEY, Geneviève. Traité de droit civil: introduction à la responsabilité. 3. éd. Paris: Librairie Générale de Droit et de Jurisprudence - L.G.D.J., 2008.

VINEY, Geneviève. Traite de droit civil: les obligations. la responsabilite: effects. Paris: Librairie Générale de Droit et de Jurisprudence - L.G.D.J., 1988.

WESTERMANN, Harm Peter. Código Civil alemão: direito das obrigações: parte geral. Tradução de Armindo Edgar Laux. Porto Alegre: Sergio Antonio Fabris Editor, 1983. 
WIEACKER, Franz. História do direito privado moderno. Tradução de A. M. Botelho Hespanha. 5. ed. Lisboa: Fundação Calouste Gulbenkian, 2015.

WIEACKER, Franz. El principio general de la buena fe. Traducción de Jose Luiz Carro. Madrid: Editorial Civitas, 1977.

ZANETTI, Cristiano de Sousa. Direito contratual contemporâneo: a liberdade contratual e sua fragmentação. São Paulo: Método, 2008.

ZIMMERMANN, Reinhard. The law of obligations: Roman Foundations of the Civilian Tradition. New York: Oxford University Press, 1996.

\section{Legislação}

BRASIL. Banco Central do Brasil. Resolução no 3.919, de 25 de novembro de 2010. Altera e consolida as normas sobre cobrança de tarifas pela prestação de serviços por parte das instituições financeiras e demais instituições autorizadas a funcionar pelo Banco Central do Brasil e dá outras providências. Brasília, DF, 2010. Disponível em: https://www.bcb.gov.br/pre/normativos/res/2010/pdf/res_3919_v4_p.pdf. Acesso em: 13 dez. 2019.

BRASIL. Constituição da República Federativa do Brasil de 1988. Brasília, DF, 1988. Disponível em: http://www.planalto.gov.br/ccivil_03/constituicao/constituicao.htm. Acesso em: 13 dez. 2019.

BRASIL. Decreto-Lei $n^{\circ} 73$, de 21 de novembro de 1966. Dispõe sobre o Sistema Nacional de Seguros Privados, regula as operações de seguros e resseguros e dá outras providências. Brasília, DF, 1966. Disponível em: http://www.planalto.gov.br/ccivil_03/DecretoLei/Del0073.htm. Acesso em: 13 dez. 2019.

BRASIL. Lei $n^{o}$ 10.406, de 10 de janeiro de 2002. Instituiu o Código Civil. Brasília, DF, Disponível em: http://www.planalto.gov.br/ccivil_03/leis/2002/110406.htm. Acesso em: 13 dez. 2019.

BRASIL. Lei $n^{o}$ 10.671, de 15 de maio de 2003. Dispõe sobre o Estatuto de Defesa do Torcedor e dá outras providências. Brasília, DF, 2003. Disponível em: http://www.planalto.gov.br/ccivil_03/leis/2003/110.671.htm. Acesso em: 13 dez. 2019.

BRASIL. Lei $n^{\circ} 13.105$, de 16 de março de 2015. Instituiu o Código de Processo Civil. Brasília, DF, 2015. Disponível em: http://www.planalto.gov.br/ccivil_03/_ato20152018/2015/lei/113105.htm. Acesso em: 13 dez. 2019.

BRASIL. Lei $n^{\circ} 13.874$ de 20 de setembro de 2019. Institui a Declaração de Direitos de Liberdade Econômica; estabelece garantias de livre mercado; altera as Leis nos 10.406, de 10 de janeiro de 2002 (Código Civil), 6.404, de 15 de dezembro de 1976, 11.598, de 3 de dezembro de 2007, 12.682, de 9 de julho de 2012, 6.015, de 31 de dezembro de 1973, 10.522, de 19 de julho de 2002, 8.934, de 18 de novembro 1994, o Decreto-Lei ${ }^{\circ}$ 9.760, de 5 de setembro de 1946 e a Consolidação das Leis do Trabalho, aprovada pelo Decreto-Lei ${ }^{\circ}$ 
5.452, de $1^{\circ}$ de maio de 1943; revoga a Lei Delegada $n^{\circ} 4$, de 26 de setembro de 1962, a Lei $\mathrm{n}^{\circ}$ 11.887, de 24 de dezembro de 2008, e dispositivos do Decreto-Lei $\mathrm{n}^{\circ} 73$, de 21 de novembro de 1966; e dá outras providências. Brasília, DF, 2019. Disponível em: http://www.planalto.gov.br/ccivil_03/_ato2019-2022/2019/lei/L13874.htm. Acesso em: 13 dez. 2019.

BRASIL. Lei $n^{\circ} 13.874$ de 20 de setembro de 2019. Institui a Declaração de Direitos de Liberdade Econômica; estabelece garantias de livre mercado; altera as Leis nos 10.406, de 10 de janeiro de 2002 (Código Civil), 6.404, de 15 de dezembro de 1976, 11.598, de 3 de dezembro de 2007, 12.682, de 9 de julho de 2012, 6.015, de 31 de dezembro de 1973, 10.522, de 19 de julho de 2002, 8.934, de 18 de novembro 1994, o Decreto-Lei ${ }^{0}$ 9.760, de 5 de setembro de 1946 e a Consolidação das Leis do Trabalho, aprovada pelo Decreto-Lei $\mathrm{n}^{\circ}$ 5.452, de $1^{\circ}$ de maio de 1943; revoga a Lei Delegada $n^{\circ} 4$, de 26 de setembro de 1962, a Lei $\mathrm{n}^{\mathrm{0}} 11.887$, de 24 de dezembro de 2008, e dispositivos do Decreto-Lei $\mathrm{n}^{\mathrm{o}} 73$, de 21 de novembro de 1966; e dá outras providências. Brasília, DF, 1965. Disponível em: http://www.planalto.gov.br/ccivil_03/_ato2019-2022/2019/1ei/L13874.htm. Acesso em: 13 dez. 2019.

BRASIL. Lei $n^{\circ} 4.595$, de 31 de dezembro de 1964. Dispõe sobre a Política e as Instituições Monetárias, Bancárias e Creditícias. Cria o Conselho Monetário Nacional e dá outras providências. Brasília, DF, 1964. Disponível em: http://www.planalto.gov.br/ccivil_03/LEIS/L4595.htm. Acesso em: 13 dez. 2019.

BRASIL. Lei $n^{\circ} 4.886$, de 09 de dezembro de 1965. Regula as atividades dos representantes comerciais autônomos. Brasília, DF, 1965. Disponível em: http://www.planalto.gov.br/ccivil_03/LEIS/L4886.htm. Acesso em: 13 dez. 2019.

BRASIL. Lei $n^{\circ}$ 8.245, de 18 de outubro de 1991. Dispõe sobre as locações dos imóveis urbanos e os procedimentos a elas pertinentes. Brasília, DF, 1991. Disponível em: http://www.planalto.gov.br/ccivil_03/leis/18245.htm. Acesso em: 13 dez. 2019.

BRASIL. Lei $n^{\circ}$ 9.307, de 23 de setembro de 1996. Dispõe sobre a arbitragem. Brasília, DF, 1996. Disponível em: http://www.planalto.gov.br/ccivil_03/leis/19307.htm. Acesso em: 13 dez. 2019.

CANADA. Code Civil du Québec (à jour au 1er décembre 2019). Disponível em: http://legisquebec.gouv.qc.ca/fr/showdoc/cs/CCQ-1991. Acesso em: 13 dez. 2019.

DEUTSCHLAND. Bürgerliches Gesetzbuch - BGB. Reichsgesetzblatt 1896, S. 195, Nr. 21, ausgegeben am 24. 08. 1896, in Kraft seit 01. 01. 1900. Disponível em: http://www.koeblergerhard.de/Fontes/BGBalleFassungen.htm. Acesso em: 13 dez. 2019.

ESPAÑA. Gobierno de España. Real Decreto de 24 de julio de 1889 por el que se publica el Código Civil. Ministerio de Gracia y Justicia. Gaceta de Madrid, núm. 206, de 25 de julio de 1889. Referencia: BOE-A-1889-4763. Disponível em: https://www.boe.es/buscar/pdf/1889/BOE-A-1889-4763-consolidado.pdf. 
ITALIA. Il Codice Civile Italiano. R.D. 16 marzo 1942, n. 262. Approvazione del testo del Codice Civile. (Pubblicato nella edizione straordinaria della Gazzetta Ufficiale, n. 79 del 4 aprile 1942). Edizione in corso di aggiornamento a cura di avv. F. Chiaves - dott.sa V. Virzì sotto la supervisione del prof. P. G. Monateri. Disponível em: http://www.jus.unitn.it/cardozo/Obiter_Dictum/codciv/Codciv.htm. Acesso em: $13 \mathrm{dez}$. 2019.

NETHERLANDS. Dutch Civil Code. (Civil Code of the Netherlands). 1838. Disponível em: http://www.dutchcivillaw.com/civilcodegeneral.htm. Acesso em: 25 dez. 2019.

PORTUGAL. Código Civil Português (actualizado até à Lei 59/99, de 30/06). Decreto-Lei $\mathrm{n}^{\mathrm{o}}$ 47.344, de 25 de novembro de 1966. Disponível em: https://www.igac.gov.pt/documents/20178/358682/C\%C3\%B3digo+Civil.pdf/2e6b36d8876b-433c-88c1-5b066aa93991.

RÉPUBLIQUE FRANÇAISE. Code Civil. [Version consolidée à la date du 23 octobre 2019]. Disponível em: https://www.legifrance.gouv.fr/affichCode.do?cidTexte=LEGITEXT000006070721\&date Texte=20191213. Acesso em: 13 dez. 2019.

RÉPUBLIQUE FRANÇAISE. Ordonnance $n^{\circ}$ 2016-131 du 10 février 2016 portant réforme $d u$ droit des contrats, du régime général et de la preuve des obligations. Disponível em: https://www.legifrance.gouv.fr/affichTexte.do?cidTexte=JORFTEXT000032004939.

Acesso em: 13 dez. 2019.

UNIDROIT Principles of international commercial contracts. Rome: International Institute for the Unification of Private Law - UNIDROIT, 2016. Disponível em: https://www.unidroit.org/instruments/commercial-contracts/unidroit-principles-2016.

Acesso em: 13 dez. 2019.

\section{Jurisprudência}

BRASIL. Superior Tribunal de Justiça - STJ. Quarta Turma. Recurso Especial $n^{o}$ 293.778/RS. Relator: Ministro Ruy Rosado de Aguiar. Julgado em 29 de maio de 2001. Disponível

https://ww2.stj.jus.br/processo/revista/documento/mediado/?componente=IMGD\&sequenc ial $=190994 \&$ num_registro $=200001353420 \&$ data $=20010820 \&$ formato $=$ PDF.

BRASIL. Superior Tribunal de Justiça - STJ. Quarta Turma. Recurso Especial $\mathrm{n}^{\mathrm{o}}$ 256.274/SP. Relator: Ministro Ruy Rosado de Aguiar. Julgado em 26 de setembro de 2000. Disponível

em: https://ww2.stj.jus.br/processo/revista/documento/mediado/?componente=IMGD\&sequenc $\mathrm{ial}=266525 \&$ num_registro $=200000395935 \&$ data $=20001218 \&$ formato $=$ PDF.

BRASIL. Superior Tribunal de Justiça - STJ. Quarta Turma. Recurso Especial $\mathrm{n}^{\mathrm{o}}$ 681.856/RS. Relator: Ministro Hélio Quaglia Barbosa. Julgado em 12 de junho de 2007. Disponível

em: 
https://ww2.stj.jus.br/processo/revista/documento/mediado/?componente=ATC\&sequencia $1=3235624 \&$ num_registro $=200401143593 \&$ data $=20070806 \&$ tipo $=5 \&$ formato $=P D F$.

BRASIL. Superior Tribunal de Justiça - STJ. Quarta Turma. Recurso Especial $\mathrm{n}^{\mathrm{o}}$ 276.025/SP. Relator: Ministro Ruy Rosado de Aguiar. Julgado em 12 de dezembro de 2000. Disponível

em: https://ww2.stj.jus.br/processo/revista/documento/mediado/?componente=IMGD\&sequenc $\mathrm{ial}=248411 \&$ num_registro $=200000899844 \&$ data $=20010312 \&$ formato $=$ PDF.

BRASIL. Superior Tribunal de Justiça - STJ. Terceira Turma. Agravo Regimental no Recurso Especial no 1.391.627/RJ. Relator: Paulo de Tarso Sanseverino. Julgado em 04 de fevereiro de 2016. Disponível em: https://ww2.stj.jus.br/processo/revista/documento/mediado/?componente=ATC\&sequencia $1=56376818 \&$ num_registro $=201302022540 \&$ data $=20160212 \&$ tipo $=5 \&$ formato $=$ PDF.

BRASIL. Superior Tribunal de Justiça - STJ. Terceira Turma. Agravo Interno no Agravo em Recurso Especial $n^{\circ} 794.821 / R S$. Relator: Ministro Marco Aurélio Bellizze. Julgado em 25 de outubro de 2016.2 Disponível em: https://ww2.stj.jus.br/processo/revista/documento/mediado/?componente=ATC\&sequencia $1=65717361 \&$ num_registro $=201502577850 \&$ data $=20161114 \&$ tipo $=5 \&$ formato $=$ PDF .

BRASIL. Superior Tribunal de Justiça - STJ. Terceira Turma. Recurso Especial $\mathrm{n}^{\circ}$ 595.631/SC. Relatora: Ministra Nancy Andrighi. Julgado em 08 de junho de 2004. Disponível

em: https://ww2.stj.jus.br/processo/revista/documento/mediado/?componente=ATC\&sequencia $1=1308529 \&$ num_registro $=200301657327 \&$ data $=20040802 \&$ tipo $=5 \&$ formato $=P D F$.

BRASIL. Superior Tribunal de Justiça - STJ. Terceira Turma. Recurso Especial $\mathrm{n}^{\mathbf{0}}$ 953.389/SP. Relatora: Ministra Nancy Andrighi. Julgado em 23 de fevereiro de 2010. Disponível em: https://ww2.stj.jus.br/processo/revista/documento/mediado/?componente=ATC\&sequencia $1=6779284 \&$ num_registro $=200701157039 \&$ data $=20100511 \&$ tipo $=5 \&$ formato $=P D F$.

BRASIL. Tribunal de Justiça do Distrito Federal - TJDF. 4 ${ }^{a}$ Turma Cível. Apelação Cível no 2006071016999-3APC. Relator: Hector Valverde Santana. Julgado em 15 de julho de 2009. Disponível em: https://pesquisajuris.tjdft.jus.br/IndexadorAcordaos$\mathrm{web} /$ sistj?visaoId=tjdf.sistj. acordaoeletronico.buscaindexada.apresentacao.VisaoBuscaAco rdao.

BRASIL. Tribunal de Justiça do Estado de São Paulo - TJSP. $10^{\text {a }}$ Câmara de Direito Privado. Apelação Cível. Processo no ${ }^{\circ}$ 1000989-57.2016.8.26.0477. Relator: Penna Machado. Julgado em 26 de novembro de 2018. Disponível em: https://esaj.tjsp.jus.br/cposg/open.do.

BRASIL. Tribunal de Justiça do Estado de São Paulo - TJSP. $14^{\text {a }}$ Câmara de Direito Privado. Apelação Cível. Processo no 0011836-20.2008.8.26.0606. Relator: Melo Colombi. Julgado em 19 de outubro de 2011. Disponível em: https://esaj.tjsp.jus.br/cposg/open.do.

BRASIL. Tribunal de Justiça do Estado de São Paulo - TJSP. $29^{a}$ Câmara de Direito Privado. Apelação Cível. Processo no 0152336-05.2008.8.26.0100. Relator: Carlos Henrique Miguel Trevisan. Julgado em 16 de setembro de 2015. Disponível em: https://esaj.tjsp.jus.br. 
BRASIL. Tribunal de Justiça do Estado de São Paulo - TJSP. $32^{\text {a }}$ Câmara de Direito Privado. Apelação Cível. Processo $n^{\circ}$ 0015762-17.2013.8.26.0482. Relator: Luis Fernando Nishi. Julgado em 26 de novembro de 2015. Disponível em: https://esaj.tjsp.jus.br/cposg/open.do.

BRASIL. Tribunal de Justiça do Estado de São Paulo - TJSP. $32^{\text {a }}$ Câmara de Direito Privado. Apelação Cív.el. Processo no 9049922-42.2009.8.26.0000. Relator: Hamid Bdine. Data de Julgamento: 30/01/2014, Data de Publicação: 01/02/2014. Disponível em: https://esaj.tjsp.jus.br/cposg/open.do.

BRASIL. Tribunal de Justiça do Estado de São Paulo - TJSP. $32^{\text {a }}$ Câmara de Direito Privado. Apelação Cível. Processo no 9049922-42.2009.8.26.0000. Relator: Hamid Bdine. Data de Julgamento: 30/01/2014, Data de Publicação: 01/02/2014. Disponível em: https://esaj.tjsp.jus.br.

BRASIL. Tribunal de Justiça do Estado de São Paulo - TJSP. $33^{\text {a }}$ Câmara de Direito Privado. Apelação Cível 0226727-23.2011.8.26.0100. Relator (a): Sá Duarte; Órgão Julgador: $33^{\mathrm{a}}$ Câmara de Direito Privado; Foro Central Cível - $25^{\mathrm{a}}$ Vara Cível; Data do Julgamento: 11/05/2015, Data de Registro: 12/05/2015. Disponível em: https://esaj.tjsp.jus.br/cposg/open.do.

BRASIL. Tribunal de Justiça do Estado de São Paulo - TJSP. 4ª Câmara de Direito Privado. Apelação Cível. Processo $n^{\circ}$ 9113042-35.2004.8.26.0000 [antigo 361.396-4/4]. Relator: Francisco Loureiro. Julgado em 12 de novembro de 2008. Disponível em: https://esaj.tjsp.jus.br.

BRASIL. Tribunal de Justiça do Estado de São Paulo - TJSP. Apelação Cível 001028251.2009.8.26.0077. Relator (a): Hamid Bdine; Órgão Julgador: $29^{\mathrm{a}}$ Câmara de Direito Privado; Foro de Birigui - $2^{\text {a }}$ Vara Cível; Data do Julgamento: 28/05/2014, Data de Registro: 28/05/2014. Disponível em: https://esaj.tjsp.jus.br.

BRASIL. Tribunal de Justiça do Estado de São Paulo - TJSP. Apelação Cível 004704381.2009.8.26.0562. Relator (a): Ferreira da Cruz; Órgão Julgador: $7^{\text {a }}$ Câmara de Direito Privado; Foro de Santos - $2^{\text {a }}$ Vara Cível; Data do Julgamento: 03/04/2013, Data de Registro: 04/04/2013. Disponível em: https://esaj.tjsp.jus.br/cjsg/getArquivo.do?cdAcordao $=6630765 \&$ cdForo $=0$.

BRASIL. Tribunal de Justiça do Estado de São Paulo - TJSP. Apelação Cível $9113042-$ 35.2004.8.26.0000. Relator (a): Francisco Loureiro; Órgão Julgador: $4^{\text {a }}$ Câmara de Direito Privado; Foro de Barueri - 5a . Vara Cível; Data do Julgamento: 13/11/2008; Data de Registro: 26/11/2008. Disponível em: https://esaj.tjsp.jus.br/.

BRASIL. Tribunal de Justiça do Rio de Janeiro - TJRJ 6 Câmara Cível. Apelação Cível. Processo $n^{o}$ 013611341.2009.8.19.0001. Relatora: Desembargadora Inês da Trindade Chaves de Melo. Julgado em 31 de maio de 2017. Disponível em: http://www1.tjrj.jus.br/gedcacheweb/default.aspx?UZIP=1\&GEDID=0004EFE129215054 CB49EAEDC6F752B17750C505545B2915\&USER=. 
BRASIL. Tribunal de Justiça do Rio Grande do Sul - TJRS. Décima Sétima Câmara Cível. Apelação Cível no 70070664370/RS 0276631-35.2016.8.21.7000. Relator: Liége Puricelli Pires. Julgado em 31 de agosto de 2017. Disponível em: http://www.tjrs.jus.br/busca/?tb=proc.

BRASIL. Tribunal de Justiça do Rio Grande do Sul - TJRS. Quinta Câmara Cível. Apelação Cível no 588.042.580/RS. Relator: Ruy Rosado de Aguiar Júnior. Julgado em 16 de agosto de 1988. Disponível em: http://www.tjrs.jus.br/busca/?tb=proc. 